\title{
Obscuring representation: contemporary art biennials in Dakar and Taipei
}

\author{
Julie Ren \\ Department of Geography, University of Zurich, Zurich, Switzerland \\ Correspondence: Julie Ren (julie.ren@uzh.ch)
}

Received: 20 December 2019 - Revised: 19 February 2021 - Accepted: 22 February 2021 - Published: 7 April 2021

\begin{abstract}
There has been a proliferation of contemporary art biennials in the past 20 years, especially in cities outside of North America and Europe. What biennials represent to their host cities and what is represented at these events reveal a great deal about the significance of this proliferation. The biennial platform entails formalistic notions of representation with regards to place branding or the selection of artists as emissaries of countries where they were been born, reside, or to which they have some kind of affinity. This notion of representation is obscured considering the instability of center and periphery, artists' biographies, practices, and references. In contradistinction to the colonial world fair, the biennial thwarts the notion or possibility of "authentic" representation. The analysis incorporates works shown at the 2018 biennials in Dakar and Taipei, interviews with artists, curators, and stakeholders, and materials collected during fieldwork in both cities.
\end{abstract}

\section{Introduction}

In Christian Nyampeta's video artwork "Life After Life," he conveys a story "about a man who dies and is accidentally buried in the wrong grave and as a result he arrives in the wrong heaven" (Personal Interview, 6 May 2018). Nyampeta employs excerpts from the film "Guelwaar" (1992) by Senegalese auteur Ousmane Sembène, in which a Christian man is accidentally buried in a Muslim grave. "Life After Life" was originally produced for the Qalandiya Festival in Jerusalem but found new resonance as part of the official exhibit at the 2018 Dak' Art contemporary art biennial.

The night before the grand opening, many artists were still preparing the exhibition, and around 3 in the morning the installation staff began to wander into Nyampeta's video room as they heard Wolof spoken through the speakers. Despite the festival being based in Dakar where Wolof is the lingua franca, French is the language more commonly heard in the exhibition areas. Nyampeta described the middle-ofthe-night camaraderie he felt with the local staff, who recognized something of their own in his work, a moment of feeling "spoken to". What is notable linguistically is not only the Wolof that is spoken but also the Arabic, French, and English subtitles that reflect the layered sources and audiences for this work.
Dak' Art is the largest international art festival on the continent and is intended as a showcase for contemporary African art, meaning that only artists of the continent and the African diaspora exhibit (Nwezi, 2013; Filitz, 2017). As part of the diaspora, Nyampeta was raised in the Netherlands, where he secured financial support from the Mondriaan Fund for his work. He was educated in London and at the time was living in New York but representing Rwanda where his family is from. This facet of representation is reduced to a name card outside his exhibition room, with country affiliation. Yet Nyampeta's concern about the ascription of being "Rwandan" was not simply about Rwandan identity or some notion of "authentic" cultural representation but rather more nuanced. He worried that being referred to as a Rwandan artist would obscure the context in which this work was produced. He bemoaned the lack of explanation in the catalogue about making this work in Jerusalem (Personal Interview, 6 May 2018).

The example raises a number of questions about the kind of stage that the contemporary art biennial offers. Taking inspiration from the case of "Life After Life" at Dak'Art, this investigation of the biennial focuses on the question of representation. Inspired by the work of Stuart Hall, and revisiting the cultural turn within geography, the question of rep- 
resentation at these biennials is considered as a practice in claiming identities, positioning places, and staging visibility $(1990,1997)$. The investigation uncovers the untenable notion of essentialized "authenticity" and the ways that identity is contested or employed, not only defined by an assignment on a name card. This kind of disruption or urge to unsettle (Ren, 2017) also connects the scholarship on representation from cultural studies to discussions about center and periphery prevalent within disciplines like art history (Gardner and Green, 2013, 2016; Whitelegg, 2020) and urban studies (Roy, 2009; Edensor and Jayne, 2012; Jazeel, 2015).

In a multi-part rumination on cultural geography, the interdisciplinary perspective this paper espouses, Ben Anderson contends that "cultural geography is once again concerned with representations" (Anderson, 2019:1120). One of the reasons that representation is garnering attention (again) in geography is because representation can itself also be construed in lively and dynamic ways (Anderson, 2019, citing Hones, 2014; Hutta, 2015; Bratt, 2016). It is no longer circumscribed to serving as the superficial veneer of a signifying system following Saussurian semiotics but is oriented to the force of representation and question of representational practice. This is the area of representation where the present paper seeks to contribute: what representational practices are active at the contemporary art biennial? How are artists and art works represented? How do they engage with the practice of representation? And what does this imply for understandings the biennial as a platform? Perhaps this serves to provide some insight into the significance of their proliferation beyond a purely instrumental view ${ }^{1}$.

The biennial platform entails formalistic and relatively static notions of representation with regards to the selection of artists as emissaries of countries where they may have been born, reside, or to which they have some kind of affinity. Indeed, cultural events are often instrumentalized as shaping place identity or branding (Häußermann and Siebel, 1993; Yudice, 2003; Yeoh, 2005). This comparative excursion to Dakar and Taipei shows how these notions of representation are obscured, considering the contested peripheral attributes of Dakar and Taipei as places, artists' biographies, and practices. By obscuring representation, the biennial resists a blunt reading of the signs and signifiers at work (Hall, 1997). In contradistinction to what might be construed as the "desperately Eurocentric" gaze (Said, 1993) of the colonial world fair, the biennial thwarts the notion or possibility of "authentic" representation (Rydell, 1999; Lagae, 2000). Instead, considering Nyampeta's layered reference points, diasporic position, and trans-local production practices, the place of culture is radically complicated - the place of the art work and artist (Is this Rwandan art? Or rather African? Dutch? Israeli? Diasporic?) and also of Dak' Art as a stage in which an "eternal

\footnotetext{
${ }^{1}$ For a review of the preoccupation of utility in the scholarship about art and the city, see Ren (2017:4-5).
}

belongingness" as African serves as both qualifier and political claim (Bhabha, 2004, citing Hall, 1988: 253-256).

After placing the biennial in its academic context, the paper situates the research from the 2018 Dakar and Taipei biennials in a relational comparative perspective. The approach to this research includes collaborating with experts from within the art communities intimately familiar with the respective biennials. This builds on literature about collaboration, highlighting the enriched perspectives that "academicpractitioner" and "insider-outsider" collaborations can generate (Louis and Bartunek, 1992; Amabile et al., 2001; Foley and Valenzuela, 2008). In Dakar, the research was conducted with Aïcha Diallo, who has covered every edition of Dak'Art as a managing editor and founding member of Contemporary And (C\&) - Platform for International Art from African Perspectives since 2012. In Taipei, the research was conducted with Yujie Huang, who helped to produce "Declaration/Documentation: Taipei Biennial 1996-2014", a retrospective exhibition on the history of the Taipei Biennial. These collaborators were key to shaping the design of the research, helping to identify and select interview partners who might offer different perspectives on the biennial and providing feedback throughout the research especially with insight into the art worlds of these respective cities. The research is based on this collaboration, as well as 27 interviews with artists, curators, stakeholders, and materials collected during fieldwork during the opening weeks of the biennial in both cities. The interviews took place in different settings: at the biennial exhibition, in private studios, in cafes, and at various art spaces.

\section{The biennial in context and in relation}

There has been a proliferation of contemporary art biennials, especially in cities outside of North America and Europe. Art biennials are exhibition events that take shape in different forms, some hosted in museums and others throughout the city in multiple venues or in public space. Some key shared characteristics are temporal (taking place every 2 years) and the object of focus being "contemporary art", however defined, selected, or commissioned. From Kampala to Kochi, the Biennial Foundation counts hundreds of biennials around the world, most of them initiated in the 1990s and early 2000s. "Most activity", writes Bruce Altshuler of this time, "would be outside the centers" (Altshuler, 2013).

In contrast to events such as the world's fairs, the art biennial remains a relatively understudied event, especially outside of art criticism in which they are often heralded as pivotal moments of art history (Deliss, 1993; Tang, 2007; Belting et al., 2009; Filipovic et al., 2010; Altshuler, 2013; Gardner and Green, 2016; Kolb et al., 2020). Beyond their influence on contemporary art, there are some distinguishing characteristics of the art biennial. Perhaps most importantly, the biennial does not move to new locations. With a few ex- 
ceptions, the art biennial is a place-based project, held usually in the same location in a city. The biennial and the city are existentially intertwined from the outset, defined as the "Taipei Biennial", for instance. Therefore, public administrations such as departments of culture or mayoral offices usually have a stake in its success and often serve as a cofounder, major funder, and patron, beyond simply serving as host.

There has been a long history of cities serving as the "stage" for various kinds of international festivals, establishing the cultural event as a particularly urban affair (Häußermann and Siebel, 1993; Gold, 2016). Research on festivals highlights the ways that they often negotiate between conflicting interests (Quinn, 2005), highlighting both its more temporary consequences for urban space (Chaudoir, 2007) and increasingly permanent impacts on shaping urban space (Gravari-Barbas, 2009). Employing festivals to promote cities as vibrant, affluent, and tolerant can also serve to simultaneously marginalize certain social groups anew (Waterman, 1998; Waitt, 2008). Specifically in the realm of cultural events, Jamie Peck has argued that culture can function as a means to camouflage more exploitative, mundane neoliberal policies like place marketing, property-led development, or interlocal competition (Peck, 2005). Brenda Yeoh builds more concretely on this critique, arguing that drawing on "local culture" as a form of "spatial imagineering" can give places a competitive edge (Yeoh, 2005). Indeed, the instrumentalization of culture for various political and economic aims has shown the ways it serves as a fungible resource for a variety of actors, policy makers, and activists alike (Yúdice, 2003).

This raises a number of questions about the relationship between art biennials and cities. If "biennials are perceived as little more than handmaidens to globalized neoliberalism" (Gardner and Green, 2013; see also Nkula-Wenz, 2019), then it might be easy to dismiss the differentiated significance of these events for those involved. Indeed it elides the entire function of place identity often central to festivals or events which extends beyond branding (Derrett, 2003). In relation to art in public space, Malcolm Miles argues that "making a place for art in the city goes along with establishing a place identity for the city as a whole" (Miles, 1997), establishing the grounds for a broad engagement with the role of artists in shaping place identity (Bain, 2003; Zukin and Braslow, 2011; Boichot, 2014). Beyond the instrumentalization of art for urban economic development to drive tourism or capitalize on the art market, the art biennial poses a number of intriguing questions about representation and place (Sassatelli, 2017). Understanding what biennials represent and what is represented at these events might contribute to a more nuanced understanding of the unequal distribution of stakes at art events (Fuller and Ren, 2019).

Given the lack of research on art biennials from an urban perspective, it is important here to note that though they have proliferated, biennials are not uniform (Vogel, 2010). The differences between the biennials in Venice, Havanna, São Paulo, or Sydney are immense in terms of their origins, goals, resources, scope, and institutionalization. In Anthony Gardner and Charles Green's review of the history of "biennials of the South," they argue that the significance of these exhibitions rested in the assemblage of artists, writers, and publics rather than in the work shown (Gardner, 2013). The lasting impact of biennials on the art world, the reason these events might be construed as "field-configuring" in shifting the discourse in the art world, was more about the informal gatherings of people than the artwork itself (Moeran and Pedersen, 2011).

Dak'Art and the Taipei Biennial exemplify diverse manifestations of the art biennial, and selecting these two sites for comparison seeks to break with the "prescribed scripts" of understanding postcolonial places in terms of their utter "Otherness" (Yeoh, 2001). Indeed, the selection of these comparative sites helps to release them from the constraining gesture of postcolonial critique that would encase these "other places" in a singular logic of urban change that is "inescapably postcolonial" (Ong, 2011). Selecting comparative sites outside of the canon (in this case the archetype of the Venice Biennial) can perhaps contribute to a more global urban studies which acknowledges the ways that urban theory is bound by its parochial legacy (Robinson, 2011; Roy, 2016) while also employing comparative tactics for a kind of experimentation (Robinson, 2016). In other words, the aim is to draw an understanding of biennials by framing Dak'Art and the Taipei Biennial in relation to each other, not as a variation of Venice.

Relational comparison takes inspiration from the seminal work of Doreen Massey to consider the ways that places do not exist in isolation but as the outcome of relations (Massey, 1995, 2011). It enjoys a new attention among scholars concerned about relating places to each other in ways that are meaningful but not necessarily in terms of prescribed notions of similarity or difference (Ward, 2010; Robinson, 2011; Hart, 2018). Therefore, the selection of Dakar and Taipei is not based on factors like population or GDP but rather about the legacies of the biennials in these two cities. This study would certainly be enriched by an expanded study of sites (Bienal de São Paulo, Ghetto Biennale in Port-au-Prince, Istanbul Biennial, among many others) which might offer perspectives complicating the present findings. As a matter of limited resources and travel restrictions, the present findings offer a first step.

Dak'Art and the Taipei Biennial offer a valuable starting point for a number of reasons. Both are recognized as important dates in the art calendar within their regional African and Asian contexts, as well as internationally (Brown, 2006; Yen, 2019). Originally a literature festival in 1990, Dak'Art was established as a festival of contemporary art in 1992 and is one of the largest contemporary art festivals today. They invite international curatorial teams to shape each edition. The Taipei Biennial was also initiated in 1992 with the unique 
characteristic that for many years (from 2000-2010), it invited prominent "international" curators to work with a "local" curator in designing each biennial. Whereas earlier editions of the Taipei Biennial focused on providing a platform for Taiwanese artists, the curatorial direction is less regionally specific and more thematic than Dak'Art. The Dak'Art exhibition makes use of multiple location within the city: the Ancien Palais de Justice, Musée de l'Institut Fondamental d'Afrique Noire (IFAN), and hundreds of sites as part of the "OFF" program located in various spaces in the city, as well as neighboring cities like Saint-Louis almost $300 \mathrm{~km}$ to the north and Gorée Island accessible by a ferry boat for the edition in 2018. The Taipei Biennial inhabits the Taipei Fine Arts Museum (TFAM) in the Zhongshan District sprawling over multiple floors including installations in the atria, performances in the courtyard, and lectures in their auditorium, though previous editions have also ventured into venues outside of TFAM. In order to understand the shared significance of these biennials for their respective cities, some further historical context helps.

Dakar and Taipei are both places whose emergence as cities coincided with colonialism; they served as important port cities for the French and Japanese colonial empires, respectively. With important waterway locations, their geopolitical and economic significance implies that their rise as cities was based in colonial power struggles. The Japanese made Taipei the seat of the colonial government giving it an important political function (Marsh, 1996:84). As the capital of French West Africa, and because of its critical port function, it has been argued that "[o]f the many colonial cities that the French constructed along the African coastline, none was less African and more imperial than Dakar" (Betts, 1985). Indeed, the colonial occupancy of both cities shaped them culturally in influential ways. Whereas Dakar became the project of a post-colonial government intent on constructing the city in the form of a metropolis, Taipei's urban landscape is marked by a constant changing of ruling values. The first president of Senegal, Léopold Sédar Senghor, famously sought to make Dakar a sub-Saharan African Athens (see, e.g., Cassirer, 1967) while simultaneously coining the concept of négritude, developing a common identity around blackness as a means to reject the racist ideologies of colonialism (see, e.g., Wilder, 2015). Pan-Africanism and the associated politics of visibility were especially prevalent in early editions of Dak' Art.

Contestations around identity were also evident in early editions of the Taipei Biennial and remain present in Taipei where numerous regime changes corresponded with disruptions culturally and politically. In Taipei: City of Displacements, Joseph Allen focuses on the material outcomes when these cultural displacements are made visible - at times showing Taiwanese reverence for Japanese aesthetics in architecture, at times revealing the ways the Japanese colonialists embraced Qing Dynasty aesthetics (Allen, 2012). Even a fleeting look at some significant historical episodes of each city demonstrates the significance of cultural contestations through the complex modes of cultural referencing. This makes them potentially rich sites for comparison with regards to the practices of representation, especially given the ostensibly similar format of the art biennial.

In 1986, at the opening speech of the Second Havana Biennial, which aimed to present art from the "so-called Third World", the president of the international jury Ida Rodriguez Prompolini reflected on the position of the jury:

\begin{abstract}
All of us who make up the jury are conscious that the situation in which artists find themselves in the various countries participating in this exhibition is different. In some cases, culture exists as a public good to which some have the right and access, though not the majority; in other cases, cultural expressions are a way of protecting the country's own identity, a search for ways of preserving their authenticity, and ultimately, for their culture to survive. (Altshuler, 2013:249)
\end{abstract}

This perspective expresses the ways that the intentions for these "Third World" biennials might be "different" and emphasizes the range of contextual differences related to resources and access. The statement highlights important contextual details such as financial differences in access to resources or political differences in the right of expression. The focus on "country", however, also underscores how this view of the biennial might have facilitated a static, essentialized idea of culture which was nationally bounded.

Ugochukwu-Smooth Nzewi's scholarship on biennials rejects this type of cultural nationalism and argues that Dak'Art offers an expanding set of artistic references (Nzewi, 2013, 2018). These shifts are evident when contrasting the work shown at the International Congress of African Culture in 1962 or the first Festival Mondial des Arts Nègres in 1966 or even the first editions of Dak'Art. These exhibitions illustrate the ways that culture, as with cultural practices, are constantly in flux (Hall, 1997). This is the shape-shifting context for the practices of representation drawn from the 2018 editions of Dak'Art and the Taipei Biennial.

\section{Practices of representation}

\subsection{Decentering places}

The agonistic practices of representing place is connected to the ways these biennials relate to a map of the art world with increasingly unstable centers. That biennials have often been seen as a form of place-branding, in marketing cities and countries (Lee, 2013; Lu, 2017), is based on the forms of static representation particularly concerned with demarcations of center and periphery. These are not biennials that represent "the center" (Altshuler, 2013) but rather a "periphery" (Marchart, 2014). Oliver Marchart contends, however, that these biennials on the so-called periphery are destabiliz- 
ing the centrality of the "west" in the landscape of art world destinations.

Though they may be in a destabilizing process, this kind of geographic demarcation was captured by several curators in their interviews. As described by Cosmin Costinas, a part of the international curatorial team at Dak' Art in 2018 who is based in Hong Kong and familiar with both biennials, Senegal and Taiwan are "marginal countries of their respective continents, and both having like an oversized intellectual production... Up to a point, I think both places claim a certain relevance for the entire continent" (Personal Interview, 5 May 2018). Neither city is particularly large in their respective regions, which highlights perhaps why certain cities stand to gain more by hosting such an event. As a curator and "concierge" of Dak'Art who has been involved since its inception, N'Goné Fall flatly states the political aims of "young biennials." Their thinking is, "if we cannot move to the center, then let's move the center to us" (Fall, 2002). The key is to shift the proximity to the art world, which is attained by making these places destinations in order to reduce the perceived socio-spatial distance (Fuller and Ren, 2019).

Curator Chang Fang-Wei expands on this notion of the center: "In Paris it's never ever need a biennial, why? Paris is very famous and packed with so many art and culture institutions and art events. Like in New York you also don't need a biennial" (Personal Interview, 24 November 2018 and 27 February 2021). As a director of the biennial for many years, she was unambiguous about the original intention when starting the Taipei Biennial, the aim from the beginning was to put Taipei on the map - and that although it was a small biennial, it was also "very strong" (Personal Interview, 24 November 2018). Putting Taipei on the map also implied defining Taipei, shaping the way it might claim its own identity. The biennial served as a platform to explore the question of Taiwanese identity following the end of a period of martial law and when lifetime politicians were forced to retire and censors on television were removed. Co-curator of the Taipei Biennial in 2004, Amy Cheng describes this period: "We release the Martial Law in 1987. So after the '90s, it's like booming era that everybody is like get very excited, and they do anything they want. It's kind of like deconstruction. Deconstruct everything, including all the old institutions, old school or old system" (Personal Interview, 22 November 2018). In 1996, the Taipei Biennial was titled "The Quest for Identity" and featured six Taiwanese curators who only invited local artists to participate.

This critical stance remains a legacy of the Taipei Biennial, which enjoys a freedom from censorship that Manray Hsu, co-curator of the Taipei Biennial in 2000 and 2008, argues is one of its most important attributes:

Taipei Biennial can be very critical, can be very political ... so there's a thing it distinguishes itself from other Asian biennials... For example censorship. We have no censorship here. If you go to
China of course censorship is very serious. Southeast Asia also. And some countries it's not like political censorship but this kind of more conservative art system. For example like Japan. (Personal Interview, 17 November 2018)

Dakar in the 1990s was also experiencing a shift following a devastating period of structural adjustment policies that decimated the cultural life. N'Goné Fall recalled how Dakar was not always on the cultural periphery, reminiscing about her childhood in Dakar when she was sent to buy cigarettes for Picasso who was visiting for a show:

You had a workshop with Pablo Picasso and you had no idea it was just this old man with his white short ... but all those things, they stay with you ... You don't understand everything but you know that, okay, this place there's a sense of freedom and they are redefining what it means to be urban, African, modern. So that was my experience of Dakar in the 70s and 80s. (Personal Interview, 8 May 2018)

It resonates with Taipei's exploration of freedom following the release from martial law, and it also complicates the cultural map, undermining the intransigence of these presumed marginalities.

\subsection{Contentious identities}

When N'Goné Fall was involved in initiating Dak'Art in the 1990s, she insisted that "the one thing that we made very clear when we asked to have a biennial was, whatever happens, curators have to be African. Because we didn't have enough platforms for ourselves" (Personal Interview, 8 May 2018). To create a platform "for ourselves" parallels the scholarship seeking to place Dak'Art in a "purely African genealogy." Cédric Vincent argues that although it is rather "contrived" to put Dak'Art in the same lineage as the 1966 Festival Mondial des Arts Nègres and in the lineage of Senghor, it also functions as "a convenient way to claim continuity with a prestigious cultural event from the past and to situate the modern exhibition within a purely African genealogical context... [it] allows Dak'Art to reflect on itself within a narrative rooted outside the Venice Biennale" (Vincent, 2015).

In contrast to situating their biennial outside of the canon, the Taipei Biennial was keen to connect to perceived centers of art. Following the 1996 edition focused exclusively on local Taiwanese curators, artists, and topics, they had a 10 year period in which the Taipei Biennial would be co-curated by a "local" and an "international" curatorial partnership. It served to reinforce what Chin-tao $\mathrm{Wu}$ has described as the "enduring hierarchy" within biennial systems (Wu, 2009). At the time, the politically contentious issue of Taiwanese "national" identity served to often exclude Taiwanese artists in 
the international art world (Lu, 2017). The key example of this would be the Taiwan Pavilion at the Venice Biennale, a contentious platform as China does not recognize Taiwan as its own country $(\mathrm{Lu}, 2013)$. Yet the biennial structure, its intentions for putting Taipei on a map, and the position of an international curator selected first to give the biennial direction and a "local" curator who supported them played into what curator and scholar Lu Peiyi describes as "a fantasy about the Western, Euro-American Centre" (Lu, 2017). Amy Cheng was more explicit about "this myth of what is international" when she asked "is the Asian curator international or we need a curator from Western world and we think it's international?" (Personal Interview, 22 November 2018).

Artist Au Sow Yee who exhibited at the Taipei Biennial 2018 also commented on the experience of marginality within Taiwan, given these fraught debates around Taiwanese identity:

It always has a conflict in its own identity, or its perception... There are some internal conflicts although when you see people, they are always very polite... Sometimes there are double standards. Like, they are polite with people that is the same color. Or if you are in different accent, if you are speaking Mandarin, if you go to Taipei main station on a Sunday when there are a lot of Southeast Asian, Indonesian gathered, immigrant workers gathered in the station, sometimes you can just see [it on] people's face. (Personal Interview, 20 November 2018)

Indeed, the question of marginality is complicated here through the experience of prejudice in Taipei. There are not only persistent hierarchies within the art world that determine centers and peripheries ( $\mathrm{Wu}, 2009)$ but also in these diverse host cities where not all artists are able to participate alike. It highlights how center and periphery are not only cartographic locations standing in relation to elsewhere but also embodied notions that demand some consideration of the representation of artists within the biennial.

As the embodiment of these demarcations of center and periphery, artists are themselves a locus through which to understand the function and practice of representation at biennials. Here, the function of representation is less bound by presumed notions of national identity but rather a practice of strategic instrumentalization. N'Goné Fall explained this situation in a lecture:

The individualities emerging from the African continent are constantly torn between the periphery and the center. The authenticity they are supposed to represent by living in Africa, trap them into some absurd situations. The typical example is the jury of the Dakar biennial. Half of the members are Westerns, often unfamiliar to these art forms, but commissioned to select from slides and pho- tographs, the artworks representing the artistic tendencies of Africa from Cairo to Cape Town. Today, some artists are contesting the legitimacy of the biennial. In Europe and the United States, the inclusion of these artists is often based on representation: identity as a social or political weapon. (Fall, 2002)

Indeed, in interviews with artists and curators, many elements of their biographies emerged that indicated a shared pedigree of education at European art institutions or engaging with some notion of contemporary "western" art. Cheikh Ndiaye, a Senegalese artist exhibiting at Dak'Art in 2018 explained that he first attended art school in Dakar but then moved to France where he "started again everything ... because the way we make art here was totally different than the way people make art in France. They have something against painting, for instance [laughing]" (Personal Interview, 2 May 2018). The practice of representation is here not only embodied in the figure of the artist but also through the choice of media in their work.

A co-curator of the Taipei Biennial in 2018 was the artist Mali Wu, who has been described as the "'god-mother' of Taiwan's socially engaged art" (Bo, 2016). She studied sculpture at the Kunstakademie in Düsseldorf in the 1980s with Günther Uecker, among others. Likewise, the curator Amy Cheng recalled the following in her studies of western art history in the 1990s:

There's a gap in between what I study and what I see in Taiwan. It's totally two different contexts. And I remember my thesis, I write about Jackson Pollock. Of course I love Jackson Pollock's art, so I chose to write about him. But after I go to Taipei Biennial or I meet more and more artists from Taiwan, and I started to question that. What is the purpose that we have to study Western art history? And what does that mean for us? (Personal Interview, 22 November 2018)

Cheng went on to live in Canada and began curating exhibitions abroad when she decided to turn her focus to Taiwan. Notably, it was her time abroad that drew her attention back to Taiwan.

Understanding identity as a weapon implies questioning the nature of difference entrenched in these representations of the "west", an enduring issue within art history in terms of its narrow frames of Eurocentric reference points. In a lecture at the Dak'Art 2018 conference "Rencontres et échanges: Arts contemporains africains et transformations des cadres intellectuels et normatifs" held at the Cheikh Anta Diop University of Dakar, Simon Gikandi discussed the way that African art was "defined in its difference from the rest of the world, it's confined to a prison house of radical difference... locked in a European episteme" (4 May 2018, see also Gikandi, 2003). Gikandi showed how art produced 
in Africa at the same time as "modern" art in Europe was nonetheless situated in an ancient historical time in the past. This epitomizes the critical stance postcolonial scholarship takes about the ways that modernity itself would forever mark non-Europe as irreducibly different, forever "catching up" (Said, 1978; Bhabha, 2004; Spivak, 2006; Robinson, 2011; Roy, 2016).

Fang-Wei Chang was skeptical of the critiques she has received related to this marking of difference in relation to authenticity:

Certain people think my aesthetic approach is very Western. That's how they criticize... But think about it: if you stop using iPhone, then you stop 'some part' of the colonial. If you stop putting on those clothes - everything you're wearing now, most are Western - then you become 'real local', these are just some rough samples. So, what exactly you mean by 'you're local'? Also, how much time or how many generations you have to live at one place in order to become 'local'? (Personal Interviews, 24 November 2018 and 27 February 2021)

The notion of essentialized differences of what constitutes "local" are thwarted in her questioning about what could possibly constitute a "real local" aesthetic or curatorial approach. The practice of authentic representation is impossible, she argues, as there is no such thing as a "real local" untouched by the "west."

Artists also point to the ways that these differences, or presumptions of difference, were not their problem. They displaced the responsibility of interpretation and rather employed their identity for access, resources, and to render themselves more accessible. Taiwanese artist Ting-Tong Chang showing at the Taipei Biennial in 2018 explained his adaptation to European audiences in this interview excerpt:

TTC: When I show in European countries sometimes they put my nationality as Chinese artist. Or they will describe me as like 'Cheng grew up in modern China.' Of course I never grew up in 'modern China' but I think sometimes the term Chinese it just, it can refer to cultural, it can be referring to regional definition. So I don't really have a problem with that. I only have a problem when because a lot of time even at shows outside Taiwan, I still apply for Taiwanese funding. And if the organizers still put my name with the nationality Chinese then I have problem with Taiwanese government. So it's only practical reasons.

JR: So it doesn't bother you?

TTC: No it doesn't really bother me. Because sometimes actually it's easier for the [European] audience to grasp the idea, or can put you in some- how historic or regional position. (Personal Interview, 22 November 2018)

It evinces a highly pragmatic view of representation; it matters when it poses problems for access to resources from the Taiwanese government or when he is presenting to an audience that might not be able to differentiate between China and Taiwan. But, and despite the political implications of this differentiation, Cheng found these labels inconsequential for understanding his work. The pragmatic view is entwined here with the powerful function of an ignorant European audience. This view of the confused European was reinforced by the artist Au Sow Yee: as a Malaysian artist based in Taiwan, she was often overlooked by European curators who were looking for Taiwanese artists in Taipei and Malaysian artists in Kuala Lumpur (Personal Interview, 20 November 2018).

As a prerequisite to participate in Dak'Art, artists must represent an African country or its diaspora, but when asked about this, Ntone Edjabe was incisive. As a former juror of Dak'Art among other biennials, he described this practice of representation as strategic:

I think, the artists are constantly negotiating this, you know? A lot of these artists are participating here as Moroccans, just participated as something, as French last week. It's not a one-way instrumentalisation, I think it's mutual... a lot of them are conveniently African just this week. (Personal Interview, 4 May 2018)

What it means to be "conveniently African" was complicated when Dak'Art allowed artists of the African diaspora to participate. This process of opening up participation was something that Cheikh Ndiaye welcomed, "Because we opening it. And the more we do that, the more it makes sense. Because being African is more complex than being born in Africa, being black, or something" (Personal Interview, 2 May 2018). It underlines Stuart Hall's writing on diaspora as an unsettling of cultural identity, to think about identity as something "never complete, always in process, and always constituted within, not outside, representation" (Hall, 1990).

\subsection{Practicing art}

Christian Nyampeta's concern with attributions to his work "Life After Life" (from the Introduction) was not about his Rwandan heritage, his upbringing in the Netherlands, his education in the United Kingdom, or his residency in the United States. He laughed about the fact that Dak'Art had mistakenly labeled him as "Rwandan/German". Rather, he found it important that people understood this work was produced in Palestine, with resources from the Mondriaan Fund, which he had access to because of his upbringing in the Netherlands. He bemoaned the lack of information about the context in which the work was produced, which might help other artists (Personal Interview, 6 May 2018). Here, the concerns about 
the methods of representation shift to the production of the artwork.

Indeed, interviews from Dak'Art and the Taipei Biennial suggest that understanding the artist, the art, or the place is more complicated than a correct label on the wall. Rather, it is the practices of accommodating, appropriating, or expanding various identities in the course of producing and exhibiting artwork that renders representation an interesting point of analysis. This is echoed by N'Goné Fall, who argued "we don't have to think about it as a representation because nobody is trying to say 'This is the contemporary African art production on the continent in 2018'. It's not about that. It's about him as a curator, he has the freedom to come with the concept he wants" (Personal Interview, 8 May 2018). In this case, she was specifically referencing Simon Njami, the artistic director of Dak' Art who developed the biennial concept in 2018 and invited the curators.

The practices of representation extend from contestations of place, of person, and of the form of art itself. Simon Njami makes his perspective on this clear in Platform Africa: "We're not talking about 'African' whatever. We're talking about photography" (Silva et al., 2017:19). For Taipei Biennial 2018 co-curator Mali Wu, who does not consider herself a curator, it was about ecosystem. She sought to bring in different audiences and included a number of non-government organizations (NGOs), activists, and researchers alongside artists in the exhibit. Among them was the Indigenous Justice Classroom, an activist group who had been protesting at the Presidential Palace for more than $600 \mathrm{~d}$ by the time the Taipei Biennial 2018 opened. They were protesting the exploitation of indigenous land in Taiwan. In the course of the biennial, the protest in the city had been shut down, but the simulacrum in the exhibition space, as well as teach-ins and events, continued. The biennial served as a kind of spatiotemporal extension of the political protest.

This relates to the analysis of artist Hong-Kai Wang, who has exhibited at the Taipei Biennial and also engages with questions of indigeneity and difference in her art. Citing Kamau Braithwaite (1984) about the language of aesthetic representation, she asked "Is it really possible to translate something that happened outside the museum space into a museum space? What if it cannot be translated?" (Personal Interview, 23 November 2018). In other words, the indigenous protest functions politically in different ways when it is relegated to the exhibition space.

The art biennial as understood through practices of representation suggests that it is a platform through which a multitude can be accomplished in terms of closing proximities or decentering points of reference. It is a forum in which artists appropriate and subvert expectations or claims to identity in order to be seen. It powerfully shapes artistic discourse and continues to venture further afield - from indigenous protests in the main exhibition to nominating Bruno Latour as curator for 2020-2021. Yet the reference to Braithwaite is also a reminder about the significance of the language being spoken and establishing a language of aesthetic representation that is not merely a "dialect" (Braithwaite, 1984). In the brief final thoughts are some reflections about obscurity, Édouard Glissant's notions of opacity, and the many questions this comparative study evokes.

\section{Conclusion: obscure, not quite opaque}

A contemporary of Braithwaite, Glissant argued for opacity as a mode of resisting domination entrenched in the mode of understanding or relation. This would be exemplified in the idea that in order for Dak'Art or the Taipei Biennial to be understood, it must define itself as some variant of the Venice Biennial. Glissant argues for opacity. By resisting understanding, it guarantees the right not to be graspable: "The opaque is not the obscure, though it is possible for it to be so and be accepted as such. It is that which cannot be reduced, which is the most perennial guarantee of participation and confluence" (Glissant, 1997). Like Vincent's history of Dak'Art (2014), the concept of opacity proposes an idea of the biennial that is irreducibly different and thus can enjoy a genealogical legacy irrespective of canon.

Yet biennials are fundamentally a stage where artists and curators alike strategically appropriate the platform for their diverse interests and to find an audience or create new destinations. Despite different interests, the function of the biennial is to facilitate visibility, which seems fundamentally irreconcilable with the propositions of opacity. Still, it is unclear with all this visibility whether these platforms might represent more than a conglomeration of diverse interests. Contemporary art biennials are not Crystal Palace exhibitions in the sense of staging nationalism or representing the outside world inside a glass facade (Sloterdijk, 2005; Martini, 2011). In thwarting any stable notion of "authenticity", the extent to which the "world" is on display or some notion of national identity is being staged is circumscribed by the practices of representation evident in this comparative study of Dak'Art and the Taipei Biennial.

This study notionally confirms Marchart's contention that biennials are functioning to destabilize the centrality of the "west" in the art world (Marchart, 2014). By positing Dak'Art and the Taipei Biennial in relation to one another, and by eliciting voices from the biennial, it also becomes clear that the stability of the "periphery" is to be contested. The politics of inclusion and voice give way at times to a recalibration of identity. In other words, the issue of representation is not about changing how under-represented countries are excluded but expanding the concept of what constitutes "Africa". Having Mali Wu co-curate was a way to expand who a curator might be and what kind of work could be shown in an exhibition space. These complex practices of representation underline the many ways that identity itself is "not an essence but a positioning" (Hall, 1990). Stuart Hall's writing on diaspora was seminal in rethinking cultural repre- 
sentation in terms of its instabilities and movements, a way of thinking that certainly resonates with the shape-shifting context of the biennial.

A parallel exhibition to the Taipei Biennial in 2018 titled "The Flying Land" was held at the JUT Museum. In Shan Shan Huang's curatorial statement, she writes about how the contemporary condition is marked by movement, the struggle over diaspora and the yearning for "final destination, inner sustenance, and home-coming that are doomed to dissatisfaction" (Huang, 2018:7). Put differently, these instabilities endemic to practices of representation which prioritize positioning over essential identities elide the ways there might still exist a yearning for something resembling home. Despite the fact that the practices of representation involve strategic positioning, there is still a desire for some fixed recognizability. Exemplary of this is the feeling of camaraderie, recognition, and the sense of feeling "spoken to" that Nyampeta's work elicited, drawing the Wolof speaking staff to his video room at Dak' Art.

Indeed, these findings suggest that further research on biennials would be fruitful to understand in particular the displacement of Eurocentric reference points from art history to urban theory, as well as to understand the intransigence of these kinds of platforms. There is certainly a need for more methodological guidance for comparative approaches as it relates to critiques of Eurocentrism in building theory about place (Peck, 2015; Robinson, 2016; Hart, 2018; Ren, 2020). Thinking with Glissant in terms of "understanding" as a relational act, for instance, it was notable how many sites of reference were offered in the interviews in Dakar and Taipei. In explaining the Taipei Biennial, Shanghai would often be used as a contrasting model of an art-market-driven biennial. Newer festivals in Bamako or the contrast to the failures of Johannesburg were often used to explain the unique qualities of Dakar. How could these reference points be empirically digested? For the intransigent power of these platforms, São Paulo would be a timely biennial to consider. The current political climate in Brazil has led to the dismantling of the cultural ministry; yet the São Paulo Biennale persists. Beyond the proliferation of biennials, what shapes the endurance and durability of these platforms?

Data availability. Further information about the interviews can be accessed by contacting the author. Due to privacy, the interviews are not made available for public access.

Competing interests. The author declares that she has no conflict of interest.

Acknowledgements. The inspiration for this project came while dreaming with Misa Dayson when she was a Humboldt Fellow in 2013. This research was made possible by Aïcha Diallo in Dakar and Yujie Huang in Taipei. I am also grateful to Lu Peiyi and Abdoumaliq Simone for some of the research contacts. Additional thanks to Nadja Scherff for her assistance.

Review statement. This paper was edited by Myriam HoussayHolzschuch and reviewed by three anonymous referees.

\section{References}

Allen, J. R.: Taipei: City of Displacements, Univerosity of Washington Press, Washington, 2012.

Altshuler, B.: Biennials and Beyond: Exhibitions That Made Art History 1962-2002, Phaidon, London, 2013.

Amabile, T. M., Patterson, C., Mueller, J., Wojcik, T., Odomirok, P. W., Marsh, M., and Kramer, S. J.: Academic-Practitioner Collaboration in Management Research: A Case of Cross-Profession Collaboration, Acad. Manage. J., 44, 418-431, 2001.

Anderson, B.: Cultural geography II: The force of representations, Prog. Human Geogr., 43, 1120-1132, 2019.

Bain, A. L.: Constructing contemporary artistic identities in Toronto neighbourhoods, The Canadian Geographer/Le Géographe canadien, 47, 303-317, 2003.

Belting, H., Buddensieg, A., and Araújo, E. (Eds.): The global art world: audiences, markets, and museums, Hatje Cantz, Ostfildern, 2009.

Betts, R. F.: Dakar: Ville Impériale (1857-1960), in: Colonial Cities, edited by: Ross, R. J. and Telkamp, G. J., Springer Netherlands, Dordrecht, 193-206, 1985.

Bhaba, H.: The Location of Culture, Routledge Classics, Oxon, 2004.

Bo, Z.: An Interview with Wu Mali, Field: A Journal of Socially Engaged Art Criticism, available at: http://field-journal. com/issue-3/an-interview-with-wu-mali (last access: 17 December 2019), 2016.

Boichot, C.: Les quartiers artistiques: territoires en construction. Regards croisés sur Montreuil (Île-de-France) et Neukölln (Berlin), Annales de geographie, 698, 1088-1111, 2014.

Brathwaite, E. K.: Nation Language, History of the Voice: The Development of Nation Language in Anglophone Caribbean Poetry, New Beacon, London, Port of Spain, 1984.

Bratt, J.: The Spirit Wanders with Things: A Literary PostPhenomenology, Literary Geogr., 2, 182-199, 2016.

Brown, C.: A Global Africa at Dak'Art 7, African Arts, 39, 60-61, 2006.

Cassirer, T.: Africa's Olympiad of the Arts: Some Observations on the Dakar Festival, Massachusetts Rev., 8, 177-184, 1967.

Chaudoir, P.: La ville événementielle: temps de l'éphémère et espace festif, Géocarrefour, 82 , https://doi.org/10.4000/geocarrefour.2301, 2007.

Deliss, C.: The Dakar Biennale 92: Where internationalism falls apart, Third Text, 7, 136-141, 1993.

Derret, R.: Making Sense of How Festivals Demonstrate a Community's Sense of Place, Event Manage., 8, 49-58, 2003.

Edensor, T. and Jayne, M.: Urban Theory Beyond the West: A world of cities, Routledge, New York, 2012. 
Fall, N.: Compromise and conflict, the shift of African art, available at: https://resartis.org/res-artis-conferences/past-conferences/ helsinki-2002/ (last access: 20 October 2018), 2002.

Filipovic, E., Ovstebo, S., and Van Hal, M. (Eds.): The Biennial Reader: An Anthology on Large-scale Perennial exhibitions of Contemporary Art, Bergen Kunsthall, Bergen, 2010.

Fillitz, T.: The Biennial of Dakar: Scales of Art Worlds-Networks, in: Ethnographies of Conferences and Trade Fairs: Shaping Industries, Creating Professionals, edited by: Høyer Leivestad, H. and Nyqvist, A., Springer International Publishing, Cham, 107127, 2017.

Foley, D. and Valenzuela, A.: Critical Ethnography: The Politics of Collaboration, in: The Landscape of Qualitative Research, edited by: Denzin, N. K. and Lincoln, Y. S., Sage Publications, Thousand Oaks, CA, 2008.

Fuller, M. and Ren, J.: The Art Opening: Proximity and Potentiality at Events, Theor. Cult. Soc., 36, 135-152, 2019.

Gardner, A. and Green, C.: Biennials of the South on the Edges of the Global, Third Text, 27, 442-455, 2013.

Gardner, A. and Green, C.: Biennials, Triennials, and Documenta: The Exhibitions that Created Contemporary Art, WileyBlackwell, Oxford, 2016.

Gikandi, S.: Picasso, Africa, and the Schemata of Difference, Modernism/modernity, 10, 455-480, 2003.

Glissant, É.: Poetics of Relation, The University of Michigan Press, Ann Arbor, 1997.

Gold, J. R.: Cities of Culture: Staging International Festivals and the Urban Agenda, 1851-2000, Routledge, London, 2016.

Gravari-Barbas, M.: La "ville festive" ou construire la ville contemporaine par l'événement. (The "Festival City": urban events and contemporary city building), Bulletin de l'Association de Géographes Français, 86, 279-290, 2009.

Hall, S.: The Hard Road to Renewal, Verso, London, 1988.

Hall, S.: Cultural Identity and Diaspora, in: Identity: Community, Culture, Difference, edited by: Rutherford, J., Lawrence and Wishart, London, 222-237, 1990.

Hall, S.: Representation: Cultural representations and signifying practices, Sage Publications, London, 1997.

Hart, G.: Relational comparison revisited: Marxist postcolonial geographies in practice, Prog. Human Geogr., 42, 371-394, 2018.

Häußermann, H. and Siebel, W.: Die Politik der Festivalisierung und die Festivalisierung der Politik, in: Festivalisierung der Stadtpolitik: Stadtentwicklung durch große Projekte, edited by: Häußermann, H. and Siebel, W., VS Verlag für Sozialwissenschaften, Wiesbaden, 7-31, 1993.

Hones, S.: Literary Geographies: Narrative Space in Let The Great World Spin, Palgrave Macmillan, New York, 2014.

Huang, S. S.: The Flying Land (6 Oct 2018-20 Jan 2019), Jut Art Museum, Taipei, 2018.

Hutta, J. S.: The affective life of semiotics, Geogr. Helv., 70, 295309, https://doi.org/10.5194/gh-70-295-2015, 2015.

Jazeel, T.: Between area and discipline: Progress, knowledge production and the geographies of Geography, Prog. Human Geogr., 40, 649-667, 2015.

Kolb, R., Pate, S., and Richter, D. (Eds.): Contemporary Art Biennials - Our Hegemonic Machines in Times of Emergency, OnCurating, 46 pp., available at: https://www.on-curating.org/files/ oc/dateiverwaltung/issue46/OnCurating_Issue46_WEB.pdf (last access: 1 April 2021), 2020.
Lagae, J.: Displaying authenticity and progress: Architectural representation of the Belgian Congo at international exhibitions in the 1930s, Third Text, 14, 21-32, 2000.

Lee, Y.: The Crisis and Opportunity of Biennials, in: Shifting Gracity: World Biennial Forum No. 1, edited by: Hou, H. and Bauer, U. M., Hatje Cantz, Ostfildern, 2013.

Louis, M. R. and Bartunek, J. M.: Insider/Outsider Research Teams: Collaboration Across Diverse Perspectives, J. Manage. Inq., 1, 101-110, 1992.

Lu, P.: To Be or Not to Be a National Pavilion: Taiwan Pavilion and Hong Kong Pavilion at Venice, Yishu: J. Chinese Contemp. Art, 12, 38-60, 2013.

Lu, P.: Why Don't We Sing? Rethinking the Curatorial Mechanisms of the Taipei Biennial for the First Twenty Years (1996-2016), J. Art Theor. Pract., 104-126, https://doi.org/10.15597/jksmi.25083538.2017.24.104, 2017.

Marchart, O.: The globalization of art and the 'Biennials of Resistance': a history of the biennials from the periphery, World Art, 4, 263-276, 2014.

Marsh, R.: The Great Transformation, Routledge, New York, 1996.

Martini, F.: One Biennale, Many Biennials, in: Just Another Exhibition: Histories and Politics of Biennials, edited by: Martini, F. and Martini, V., Postmedia, Milan, 2011.

Massey, D.: Space, Place and Gender, University of Minnesota Press, Minneapolis, 1995.

Massey, D.: A Counterhegemonic Relationality of Place, in: Mobile Urbanism: Cities and Policymaking in the Global Age, edited by: McCann, E. and Ward, K., University of Minnesota Press, Minneapolis, 1-14, 2011.

Miles, M.: Art, Space and the City: Public Art and Urban Futures, Routledge, London, New York, 1997.

Moeran, B. and Pedersen, J. S.: Negotiating Values in the Creative Industries: Fairs, Festivals and Competitive Events, Cambridge University Press, Cambridge, 2011.

Nkula-Wenz, L.: Worlding Cape Town by design: Encounters with creative cityness, Environ. Plan. A, 51, 581-597, 2019.

Nzewi, U.-S. C.: The contemporary present and modernist past in postcolonial African art, World Art, 3, 211-234, 2013.

Nzewi, U.-S. C.: The Dak'Art Biennale and Global Black Cultural Politics in the Twentieth Century, Nka J. Contemp. Afr. Art, 2018, 96-109, 2018.

Ong, A.: Introduction: Worlding Cities, or the Art of Being Global, in: Worlding Cities: Asian Experiments and the Art of Being Global, edited by: Roy, A. and Ong, A., Wiley-Blackwell, Malden, 1-25, 2011.

Peck, J.: Struggling with the Creative Class, Int. J. Urban Reg. Res., 29, 740-770, 2005.

Peck, J.: Cities beyond Compare?, Reg. Stud., 49, 160-182, 2015.

Quinn, B.: Changing festival places: insights from Galway, Social Cult. Geogr., 6, 237-252, 2005.

Ren, J.: Introduction: Disruptions of a Critical Artscape, in: Art and the City: Worlding the Discussion Through a Critical Artscape, edited by: Luger, J. and Ren, J., Routledge, London, New York, 1-12, 2017.

Ren, J.: Engaging Comparative Urbanism: Art Spaces in Beijing and Berlin, Bristol University Press, Bristol, 2020.

Robinson, J.: Cities in a World of Cities: The Comparative Gesture: Cities in a world of cities compared, Int. J. Urban Reg. Res., 35, 1-23, 2011. 
Robinson, J.: Thinking cities through elsewhere: Comparative tactics for a more global urban studies, Prog. Human Geogr., 40, 3-29, 2016.

Roy, A.: The 21st-Century Metropolis: New Geographies of Theory, Reg. Stud., 43, 819-830, 2009.

Roy, A.: Who's Afraid of Postcolonial Theory?, Int. J. Urban Reg. Res., 40, 200-209, 2016.

Rydell, R.: "Darkest Africa" African Shows at America's World's Fairs, 1893-1940, in: Africans on Stage: Studies in Ethnological Show Business, edited by: Lindfors, B., Indiana University Press, Bloomington, 1999.

Said, E.: Orientalism, Vintage Books, London, 1978.

Said, E.: Culture And Imperialism, Random House, London., 1993.

Sassatelli, M.: Symbolic Production in the Art Biennial: Making Worlds, Theor. Cult. Soc., 34, 89-113, 2017.

Silva, B., Fleetwood, J., and Diallo, A.: Platform Africa, Aperture, p. 19, 2017.

Sloterdijk, P.: Im Weltinnenraum des Kapitals: Für Eine Philosophische Theorie der Globalisierung, Suhrkamp, Frankfurt, 2005 .

Spivak, G.: In Other Worlds, Routledge Classics, New York, 2006.

Tang, J.: Spectacle's Politics and the Singapore Biennale, J. Visual Cult., 6, 365-377, 2007.

Vincent, C.: A Non-linear History of Dak'Art, C\& Platform for International Art From African Perspectives, Print Edition Dak'Art 14, 4-5, 2014.

Vogel, S. B.: Biennials: Art on a Global Scale, edited by: Vogel, S. B., Springer, Vienna, 2010.

Waitt, G.: Urban Festivals: Geographies of Hype, Helplessness and Hope, Geogr. Compass, 2, 513-537, 2008.
Ward, K.: Towards a relational comparative approach to the study of cities, Prog. Human Geogr., 34, 471-487, 2010.

Waterman, S.: Carnivals for elites? The cultural politics of arts festivals, Prog. Human Geogr., 22, 54-74, 1998.

Whitelegg, I.: São Paulo \& Other Models: the Biennale in Latin America, 1951-1991, in: Modern and Contemporary Latin American \& Latino Art, edited by: Greele, R. and Sullivan, M., Blackwell, London, 2020.

Wilder, G.: Freedom Time: Negritude, Decolonization, and the Future of the World, Duke University Press, Durham, 2015.

Wu, C.: Biennials without Borders, New Left Review, available at: https://newleftreview.org/issues/II57/articles/ chin-tao-wu-biennials-without-borders (last access: 13 December 2019), 2009.

Yen, J. C. T.: A view from the inside: Taipei's art scene, Financial Times, available at: https://www.ft.com/content/ c5f9eb16-0f44-11e9-b2f2-f4c566a4fc5f, last access: 3 September 2019.

Yeoh, B.: Postcolonial cities, Prog. Human Geogr., 25, 456-468, 2001.

Yeoh, B. S. A.: The Global Cultural City? Spatial Imagineering and Politics in the (Multi)cultural Marketplaces of South-east Asia, Urban Stud., 42, 945-958, 2005.

Yúdice, G.: The Expediency of Culture: Uses of Culture in the Global Era, Duke University Press, Durham, 2003.

Zukin, S. and Braslow, L.: The life cycle of New York's creative districts: Reflections on the unanticipated consequences of unplanned cultural zones, City Cult. Soc., 2, 131-140, 2011. 